\title{
Dry Matter Yield Potentials of Some Gamba Grass (Andropogon gayanus Kunth.) Accessions in the Southern Guinea Savanna of Benue State, Nigeria
}

\author{
Abel Ibrahim Okwori ${ }^{1}$, Michael Eghosa Aken'Ova ${ }^{2}$ \\ ${ }^{1}$ Department of Animal Production, Federal University of Agriculture, Makurdi, Nigeria \\ ${ }^{2}$ Department of Agronomy, University of Ibadan, Ibadan, Nigeria
}

Email address:

abelokwori@yahoo.com (A. I. Okwori)

\section{To cite this article:}

Abel Ibrahim Okwori, Michael Eghosa Aken'Ova. Dry Matter Yield Potentials of Some Gamba Grass (Andropogon gayanus Kunth.) Accessions in the Southern Guinea Savanna of Benue State, Nigeria. International Journal of Applied Agricultural Sciences. Vol. 3, No. 4, 2017, pp. 99-103. doi: 10.11648/j.ijaas.20170304.13

Received: January 8, 2017; Accepted: January 21, 2017; Published: August 9, 2017

\begin{abstract}
Benue state of Nigeria has a high potential for ruminant livestock production with its extensive grass cover of the southern guinea savanna, dominate by gamba grass (Andropogon gayanus kunth). However, this and other grasses have not been evaluated for forage utilization in the state. Investigations were therefore conducted to identify suitable genotypes among the local and introduced grasses. Forage dry matter yields of 20 accessions of $A$. gayanus, from Benue and neighbouring Kogi states were evaluated at three locations in Benue state: Makurdi $\left(7^{\circ} 43^{\prime} \mathrm{N}, 8^{\circ} 32^{\prime} \mathrm{E}\right)$. Otupka $\left(7^{\circ} 04^{\prime} \mathrm{N}, 7^{\circ} 39^{\prime} \mathrm{E}\right)$ and Yandev $\left(7^{\circ} 22^{\prime} \mathrm{N}, 9^{\circ} 02^{\prime} \mathrm{E}\right)$. forage was harvested every six weeks during the rainy season over two years in a completely randomized design with three replicates. There are significant differences in annual rainy season DM yields of the 20 A. gayanus accessions. At Makurdi, DM yields in t/ha varied from 4.7 (Acc.9) to 14.4 (Acc.2), while at Otukpa yields ranged from 7.7 (Acc.4) to 22.3 (Acc.12) and 5.7 (Acc.9) to 14.9 (Acc.18) at Yandev. Average DM yields over the three sites varied from 1.9 (Acc.3 and Acc.6) to 13.4 (Acc.10). based on the DM production, accessions 10,11 and 18 may be considered for exploitation in Benue state.
\end{abstract}

Keywords: Benue State, Dry Matter Yield, Southern Guinea Savanna

\section{Introduction}

With the domestication of ruminant animals in the Neolithic era, humankind relied entirely on natural vegetation for feed for the livestock under a system of nomadic pastoralism [7]. However, with increasing human population and the attendant pressure on land resources, the system has largely broken down giving way to more sedentary and more intensive systems. Such intensive systems have been more highly developed in temperate regions through ley farming. Apart from improvements in subsequent crop yield, following a legume or grass-legume pasture, due to improved soil fertility, improved soil structure and reduction in soil erosion [21], [17], [13].

Ruminant livestock production in Nigeria is typically storage-based. Over $80 \%$ of the herd is in the hands of nomadic pastoralists who depend solely on range and crop residues to feed their stock [1].

Hitherto, very little attention has been directed towards developing he vast areas of natural grasslands vis-à-vis livestock production in Benue State in the southern guinea savanna. It has been estimated that $A$ gayanus Kunth gamba grass, the predominant grass species constitutes $60 \%$ of the grass biomass in the natural vegetation of the region, which can contribute to livestock production [15]. Andropogon gayanus was also recognized by Rossiter et al. [16] as a highly productive grass even though, considered an invasive weed which has increased fire fuel loads seven-fold and fire intensities eight-fold in the tropical savannas of Northern Australia compared with native-dominated systems. For improved livestock production in Benue state. There is need to identify suitable genotypes of forage grass species such as A. gayanus which is abundant in the state, as well as other species. The present study was therefore embarked upon to;

Evaluate dry matter yields of Benue state local accessions of Andropogon gayanus to determine those that may be suitable for utilization in the state. 


\section{Materials and Methods}

The study was conducted in three locations viz. Makurdi $\left(7^{\circ} 43^{\prime} \mathrm{N}, 8^{\circ} 32^{\prime} \mathrm{E}\right)$, Otukpa $\left(7^{\circ} 04^{\prime} \mathrm{N}, 7^{\circ} 39^{\prime} \mathrm{E}\right)$ and Yandav $\left(7^{\circ} 22^{\prime} \mathrm{N}, 9^{\circ} 02^{\prime} \mathrm{E}\right)$ in Benue State, which lies in the Southern Guinea savanna zone of Nigeria. It comprised a two-year forage evaluation field trial viz. Evaluation of Andropogon gayanus accessions from different parts of Benue and Kogi state.

Crown splits of andropogon gayanus ectotypes were collected from 20 locations in Benue and Kogi state i.e. 17 sites from Benue state and 3 sites from Kogi state when the rainy season was sell established, the sites were ploughed and harrowed. The crown splits were planted in three locations in Benue state viz. Makurdi at the university of agriculture, teaching and research farm, Otukpa and experiment station at Yandev. Crown splits of each accession were set every $50 \mathrm{~cm}$ in single, $4 \mathrm{~m}$ long row plots spaced $1 \mathrm{~m}$ apart and arranged in a completely randomized design with three replicates. Soil samples $(0-15 \mathrm{~cm}$ depth) were taken from the three sites and analyzed for physical and chemical parameters. During the establishment year the plots were weeded as necessary to minimize weed competition and subsequently at each harvest.

In the following two years, with the full establishment of rains in June, surviving plants at the three sites were cut at 15 $\mathrm{cm}$ above ground level and the cut herbage discarded. The plots were subsequently harvested every six weeks with the third and last harvest in October eat the onset of the dry season. After each harvest except the last, nitrogen fertilizer (N: P: K, 20:10:10) was applied at a rate to supply $20 \mathrm{~kg}$ of nitrogen per hectare $(20 \mathrm{~kg} \mathrm{~N} / \mathrm{ha})$. After the last harvest, the plants were rested and allowed to grow to flowering for observation of morphological features viz. leaf and stem characteristics. At each harvest, the following parameters ere measured; plant height, fresh herbage yield and proportion of leaf in the cut herbage. The fresh herbage was sub-sampled, separated into leaf i.e. lamina and the stem with leaf sheath portions, weighed and oven-dried at $70^{\circ} \mathrm{C}$ to constant weight. Dry matter content was calculated and used to calculate forage dry matter yield per plot. All data generated were analyzed using MSS [11].

\section{Results}

\subsection{Sprouting and Stand Establishment Rates}

Sprouting varied among the A. gayanus accessions at the three trial sites resulting in dead or missing stands. A count of stand establishment revealed considerable variation among accessions within locations (Table 1). Stand establishment rates range from 20 to 100,0 to 100 and 7 to $93 \%$ at Makurdi, Otukpa and Yandev, respectively. Averaged over sites, stand establishment was significantly different among accessions with Acc.18, recording the highest level of $96 \%$ which was not significantly different from two other accessions i.e. 19 and 20 which recorded 82 and $84 \%$ respectively, but significantly different from the remaining seventeen accessions, excluding Acc. 18, accessions 19 and 20 were not significantly different from four other accessions viz. 3.6.9 and 10 with levels ranging between 67 and $73 \%$, but significantly different from the remaining thirteen accessions with levels ranging between 13 (Acc. 9) and 62\% (Acc. 11 and Acc. 12). these four accessions i.e. 3, 6, 9 and 10 were not significantly different from the values of three other accessions viz. 11, 12, and 14 with 62,62 and $60 \%$ respectively.

Averaged over accessions, however, stand establishment was not significantly different among locations with 56,59 and 50\% at Makurdi, Otukpa and Yandev, respectively.

\subsection{Proportion of Leaf and Plant Height at Harvest}

Proportion of leaf and plant height at gravest, are shown in table 2 . Accessions 1, 13, 15, 16, and 17 performed poorly in all the trial sites as a result of which no records could be obtained from them and were labeled 'no records' (nr) and were excluded from further evaluation.

The results showed that Acc.14 recorded the highest proportion of leaf of $58.33 \%$ which was significantly different from the remaining fourteen accessions viz. 2, 3, 4, 5, 6, 7, 8, $9,10,11,12,18,19$ and 20 with leaf proportions ranging between 50.00 (Acc. 6) and 55.55\% (Acc. 10). Accession 10 recorded the second highest proportion of leaf of $55.55 \%$, which was significantly different from the remaining thirteen accessions i.e. 2, 3, 4, 5, 6, 7, 8, 9, 11, 12, 18, 19 and 20 with leaf proportions ranging between 5.00 (Acc.6) and 54.54\% (Acc. 11). Accessions 6 and 8 each with $50.00 \%$ score recorded the lowest leaf proportion among all accessions though not significantly different from that of Acc.7 (50.25\%).

Table 1. Stand establishment of Andropogon gayanus accessions at Makurdi, Otukpa and Yandev.

\begin{tabular}{|c|c|c|c|c|c|}
\hline \multirow{2}{*}{$\begin{array}{l}\text { Accession } \\
\text { number }\end{array}$} & \multirow{2}{*}{$\begin{array}{l}\text { Collection } \\
\text { site }\end{array}$} & \multicolumn{3}{|c|}{ Experimental site } & \multirow{2}{*}{ Average ++} \\
\hline & & Makurdi & Otukpa & Yandev & \\
\hline & & & $\%$ & & \\
\hline 1 & Otukpa I & 20 & 0 & 20 & $13 h^{*}$ \\
\hline 2 & Makurdi I & 53 & 80 & 20 & $51 \mathrm{de}$ \\
\hline 3 & Otukpa II & 47 & 83 & 87 & $72 b c$ \\
\hline 4 & Owukpa I & 53 & 73 & 27 & $51 \mathrm{de}$ \\
\hline 5 & Naka I & 33 & 63 & 53 & 50def \\
\hline 6 & Otukpo I & 73 & 80 & 47 & $67 \mathrm{bcd}$ \\
\hline 7 & Makurdi II & 27 & 20 & 47 & $31 \mathrm{fgh}$ \\
\hline 8 & Yandev I & 40 & 27 & 67 & $45 \mathrm{efg}$ \\
\hline 9 & Katsina - Ala & 73 & 53 & 80 & $69 \mathrm{bcd}$ \\
\hline 10 & Makurdi III & 100 & 47 & 73 & $73 \mathrm{bc}$ \\
\hline 11 & Makurdi IV & 80 & 53 & 53 & $62 \mathrm{cde}$ \\
\hline $12+$ & Ankpa I & 60 & 73 & 53 & $62 \mathrm{cde}$ \\
\hline 13 & Adoka I & 20 & 60 & 53 & $44 \mathrm{efg}$ \\
\hline 14 & Owukpa II & 60 & 87 & 33 & $60 \mathrm{cde}$ \\
\hline 15 & Naka II & 20 & 53 & 7 & $27 \mathrm{gh}$ \\
\hline 16 & Makurdi V & 40 & 47 & 7 & $31 \mathrm{fgh}$ \\
\hline 17 & Adoka II & 27 & 40 & 20 & $29 \mathrm{gh}$ \\
\hline $18+$ & Idah & 100 & 100 & 87 & $96 a$ \\
\hline $19+$ & Ankpa II & 87 & 87 & 73 & $82 \mathrm{ab}$ \\
\hline \multirow[t]{2}{*}{20} & Gbajimba & 100 & 60 & 93 & $84 a b$ \\
\hline & Average/site & 56 & 59 & $50 \mathrm{~ns}$ & \\
\hline
\end{tabular}

*Means in the column followed by the same letter(s) are not significantly different at the $5 \%$ level by Duncan's multiple range test $\mathrm{ns}=$ means in the row are not significantly different

+ Kogi State accessions

++ Values are average of three sites 
Table 2. Some botanical characteristics of Andropogon gayanus accessions of Benue State.

\begin{tabular}{llll}
\hline Accession number & Collection site & ++Leaf & +Height at harvest \\
\hline & & $-\%-$ & $-\mathrm{m}-$ \\
1 & Otukpa I & $\mathrm{nr}$ & $\mathrm{nr}$ \\
2 & Makurdi I & $50.98 \mathrm{fg} *$ & 1.25 \\
3 & Otukpa II & $51.22 \mathrm{f}$ & 1.25 \\
4 & Owukpa I & $52.38 \mathrm{e}$ & 1.20 \\
5 & Naka I & $52.38 \mathrm{e}$ & 1.30 \\
6 & Otukpo I & $50.00 \mathrm{~h}$ & 1.40 \\
7 & Makurdi II & $50.25 \mathrm{gh}$ & 1.35 \\
8 & Yandev & $50.00 \mathrm{~h}$ & 1.25 \\
9 & Katsina - Ala & $53.49 \mathrm{~d}$ & 1.30 \\
10 & Makurdi III & $55.55 \mathrm{~b}$ & 1.20 \\
11 & Makurdi IV & $54.54 \mathrm{c}$ & 1.15 \\
$12+$ & Ankpa I & $51.69 \mathrm{ef}$ & 1.20 \\
13 & Adoka I & $\mathrm{nr}$ & $\mathrm{nr}$ \\
14 & Owukpa II & $58.33 \mathrm{a}$ & 1.51 \\
15 & Naka II & $\mathrm{nr}$ & $\mathrm{nr}$ \\
16 & Makurdi V & $\mathrm{nr}$ & $\mathrm{nr}$ \\
17 & Adoka II & $\mathrm{nr}$ & $\mathrm{nr}$ \\
$18+$ & Idah & $51.22 \mathrm{f}$ & 1.25 \\
$19+$ & Ankpa II & $53.49 \mathrm{~d}$ & 1.30 \\
20 & Gbajimba & $52.38 \mathrm{e}$ & $1.35 \mathrm{~ns}$ \\
\hline
\end{tabular}

* Means in the column followed by the same letter(s) are not significantly different by Duncan's multiple range test; ns $=$ no significant difference among accessions; + = Kogi State accessions; ++ = All values were average of three harvests from the three sites;

$\mathrm{nr}=$ no records owing to poor stand establishment
Plant height of six weeks' re-growth ranged from 1.15 for Acc. 11 to $1.51 \mathrm{~m}$ for Acc.14 (table 2). However, there were no significant differences among the accessions.

\subsection{Dry Matter Yield}

The total dry matter yields among accessions during the rainy season in each of the two years, the annual average yields and average yields over the trial sites are presented in Table 3. There was no record of DM yields of some accessions viz. 1, 13, 15, 16 and 17 owing to poor establishment at all the trial sites. In addition to these five accessions, there were no records for some other accessions specific to each trial site because of poor establishment. Thus, at Makurdi, there were no DM yield records for accessions 8 and 12 . There were also no yield records at Otukpo for accessions 3, 5, 6, 7, 8, 9 and 19. While at Yandev, accessions 2, 3, 4, 5, 6, 7, 12, and 19 had no data recorded. All these accessions are tagged 'no records' (nr) in the table.

Table 3. Dry matter yields of Andropogon gayanus accessions at Makurdi, Otukpa and Yandev over two years.

\begin{tabular}{|c|c|c|c|c|c|c|c|c|c|c|}
\hline \multirow[b]{2}{*}{ Acc No. } & \multicolumn{3}{|l|}{$1^{\text {st }}$ year } & \multicolumn{3}{|c|}{$2^{\text {nd }}$ year } & \multicolumn{4}{|c|}{ Annual average } \\
\hline & ++Mak. & Otu. & Yan. & Mak. & Otu & Yan. & Mak. & Otu & Yan. & All sites \\
\hline 1 & $\mathrm{nr}$ & $\mathrm{nr}$ & $\mathrm{nr}$ & $\mathrm{nr}$ & $\begin{array}{l}\mathrm{t} / \mathrm{ha} \\
\mathrm{nr}\end{array}$ & $\mathrm{nr}$ & $\mathrm{nr}$ & $\mathrm{nr}$ & $\mathrm{nr}$ & $\mathrm{nr}$ \\
\hline 2 & $10.1 a^{*}$ & $7.5 \mathrm{e}$ & $\mathrm{nr}$ & $18.6 \mathrm{a}$ & $17.6 \mathrm{~d}$ & $\mathrm{nr}$ & $14.4 \mathrm{a}$ & $12.6 \mathrm{e}$ & $\mathrm{nr}$ & $9.0 \mathrm{c}$ \\
\hline 3 & $3.1 \mathrm{~h}$ & $\mathrm{nr}$ & $\mathrm{nr}$ & $8.4 \mathrm{f}$ & $\mathrm{nr}$ & $\mathrm{nr}$ & $5.8 \mathrm{~g}$ & $\mathrm{nr}$ & $\mathrm{nr}$ & $1.9 \mathrm{~h}$ \\
\hline 4 & $3.6 \mathrm{gh}$ & $3.9 \mathrm{~g}$ & $\mathrm{nr}$ & $12.1 \mathrm{~d}$ & $11.4 \mathrm{~g}$ & $\mathrm{nr}$ & $7.9 \mathrm{f}$ & $7.7 \mathrm{~g}$ & $\mathrm{nr}$ & $5.2 \mathrm{e}$ \\
\hline 5 & $6.7 \mathrm{~cd}$ & $\mathrm{nr}$ & $\mathrm{nr}$ & $14.8 \mathrm{~b}$ & $\mathrm{nr}$ & $\mathrm{nr}$ & $10.8 \mathrm{~b}$ & $\mathrm{nr}$ & $\mathrm{nr}$ & $3.6 \mathrm{f}$ \\
\hline 6 & $4.0 \mathrm{fg}$ & $\mathrm{nr}$ & $\mathrm{nr}$ & $7.4 \mathrm{~g}$ & $\mathrm{nr}$ & $\mathrm{nr}$ & $5.7 \mathrm{~g}$ & $\mathrm{nr}$ & $\mathrm{nr}$ & $1.9 \mathrm{~h}$ \\
\hline 7 & $6.5 \mathrm{de}$ & $\mathrm{nr}$ & $\mathrm{nr}$ & $15.1 \mathrm{~b}$ & $\mathrm{nr}$ & $\mathrm{nr}$ & $10.8 \mathrm{~b}$ & $\mathrm{nr}$ & $\mathrm{nr}$ & $3.6 \mathrm{f}$ \\
\hline 8 & $\mathrm{nr}$ & $\mathrm{nr}$ & $4.3 \mathrm{~d}$ & $\mathrm{nr}$ & $\mathrm{nr}$ & $11.8 \mathrm{~d}$ & $\mathrm{nr}$ & $\mathrm{nr}$ & $8.1 \mathrm{~d}$ & $2.7 \mathrm{~g}$ \\
\hline 9 & 3.0hi & $\mathrm{nr}$ & $3.7 \mathrm{e}$ & $6.4 \mathrm{~h}$ & $\mathrm{nr}$ & $7.8 \mathrm{e}$ & $4.7 \mathrm{~h}$ & $\mathrm{nr}$ & $5.8 \mathrm{e}$ & $3.5 \mathrm{f}$ \\
\hline 10 & $7.4 b$ & $10.9 \mathrm{c}$ & $7.8 \mathrm{~b}$ & $13.4 \mathrm{c}$ & $22.6 b$ & $18.0 \mathrm{~b}$ & $10.4 \mathrm{c}$ & $16.8 \mathrm{c}$ & $12.9 \mathrm{~b}$ & $13.4 \mathrm{a}$ \\
\hline 11 & $4.4 \mathrm{f}$ & $15.1 \mathrm{~b}$ & $7.8 \mathrm{~b}$ & $6.7 \mathrm{~h}$ & $28.1 \mathrm{a}$ & $17.4 \mathrm{~b}$ & $5.6 \mathrm{~g}$ & $21.6 b$ & $12.6 \mathrm{~b}$ & $13.3 \mathrm{a}$ \\
\hline $12+$ & $\mathrm{nr}$ & $16.6 \mathrm{a}$ & $\mathrm{nr}$ & $\mathrm{nr}$ & $28.0 \mathrm{a}$ & $\mathrm{nr}$ & $\mathrm{nr}$ & $22.3 \mathrm{a}$ & $\mathrm{nr}$ & $7.4 \mathrm{~d}$ \\
\hline 13 & $\mathrm{nr}$ & $\mathrm{nr}$ & $\mathrm{nr}$ & $\mathrm{nr}$ & $\mathrm{nr}$ & $\mathrm{nr}$ & $\mathrm{nr}$ & $\mathrm{nr}$ & $\mathrm{nr}$ & $\mathrm{nr}$ \\
\hline 14 & $4.1 \mathrm{fg}$ & $7.7 \mathrm{e}$ & $4.1 \mathrm{de}$ & $7.5 \mathrm{~g}$ & $16.8 \mathrm{e}$ & $8.3 \mathrm{e}$ & $5.8 \mathrm{~g}$ & $12.3 \mathrm{e}$ & $6.2 \mathrm{e}$ & $8.1 \mathrm{~d}$ \\
\hline 15 & $\mathrm{nr}$ & $\mathrm{nr}$ & $\mathrm{nr}$ & $\mathrm{nr}$ & $\mathrm{nr}$ & $\mathrm{nr}$ & $\mathrm{nr}$ & $\mathrm{nr}$ & $\mathrm{nr}$ & $\mathrm{nr}$ \\
\hline 16 & $\mathrm{nr}$ & $\mathrm{nr}$ & $\mathrm{nr}$ & $\mathrm{nr}$ & $\mathrm{nr}$ & $\mathrm{nr}$ & $\mathrm{nr}$ & $\mathrm{nr}$ & $\mathrm{nr}$ & $\mathrm{nr}$ \\
\hline 17 & $\mathrm{nr}$ & $\mathrm{nr}$ & $\mathrm{nr}$ & $\mathrm{nr}$ & $\mathrm{nr}$ & $\mathrm{nr}$ & $\mathrm{nr}$ & $\mathrm{nr}$ & $\mathrm{nr}$ & $\mathrm{nr}$ \\
\hline $18+$ & $7.1 \mathrm{bc}$ & $9.5 \mathrm{~d}$ & $8.7 \mathrm{a}$ & $11.2 \mathrm{e}$ & $19.8 \mathrm{c}$ & $21.1 \mathrm{a}$ & $9.2 \mathrm{~d}$ & $14.7 \mathrm{~d}$ & $14.9 \mathrm{a}$ & $12.9 \mathrm{a}$ \\
\hline $19+$ & $7.3 b$ & $\mathrm{nr}$ & $\mathrm{nr}$ & $13.1 \mathrm{c}$ & $\mathrm{nr}$ & $\mathrm{nr}$ & $10.2 \mathrm{c}$ & $\mathrm{nr}$ & $\mathrm{nr}$ & $3.4 \mathrm{fg}$ \\
\hline 20 & $6.1 \mathrm{e}$ & $5.7 \mathrm{f}$ & $6.5 \mathrm{c}$ & $10.7 \mathrm{e}$ & $14.6 \mathrm{f}$ & $16.3 \mathrm{c}$ & $8.4 \mathrm{e}$ & $10.2 \mathrm{f}$ & $11.4 \mathrm{c}$ & $10.0 \mathrm{~b}$ \\
\hline
\end{tabular}

* Means in the column followed by the same letter(s) are not significantly different at the $5 \%$ level by Duncan's multiple range test

+ Kogi State accessions

++Mak. = Makurdi; Otu. = Otukpa; Yan. = Yandev; $\mathrm{nr}=$ no records owing to poor stand establishment 
Dry matter yields varied from $1.9 \mathrm{t} / \mathrm{ha}$ in accessions 3 and 6 to $13.4 \mathrm{t} / \mathrm{ha}$ in accessions 10 when averaged over sites for the two years.

\section{Discussions}

Satisfactory plant establishment starts with adequate germination of seeds and seedling emergence or a high rate of sprouting of shoots in the case of vegetative propagation [6]. This is followed by rooting and growth. Ease of establishing as reflected by high rate of germination or sprouting and rapid early growth is desirable in forage species [21]. In the evaluation of the A. gayanus accession, of Benue and Kogi states, the variation observed among them reflects genotypic differences above average establishment in different locations by some A. gayanus accessions such as accessions 10. 11 and 18 suggests their better adaptation to environmental conditions in the three locations at which evaluation was conducted.

Proportion of fresh leaf which ranged between 50\% and $58 \%$ fell within the range exhibited by $A$. gayanus accessions from the humid zone of southern Nigeria [19]. A relatively high proportion of leaf as in the present study, may be associated with improved nutritive value [5].

Most accessions were, on average $1.30 \mathrm{~m}$ in tall or less at the time of harvest. They should therefore pose no problem of accessibility for cattle. A cut-and-carry system may have to be adopted in feeding small ruminants such as sheep and goats as the plant may be too tall at the interval of cutting adopted in this trial. Shorter cutting or grazing intervals or more frequent harvests while making for shorter plants may reduce herbage yields and result in loss of stands [6], [9].

The relatively high annual DM yield of the highest yielding $A$. gayanus accessions is in agreement with those cited by Miller and Blair-Rains [10] in northern Nigeria's northern guinea savanna. The range of variation observed among the accessions would facilitate selection for high yielding accessions. High DM yields make for higher carrying capacity of pastures. Owing to the considerable declining in the DM yields at the last harvest in the year, extending the cutting interval towards the end of the rainy season may help to reduce the decline since the extension would allow for more DM accumulation [9].

The yield characteristics recorded in Makurdi indicated that DM values were generally higher than those reported by Ademosun and Baumgardt [2] for A. gayanus genotypes from Ibadan, in southwest Nigeria. These differences may reflect genotypic and environmental differences.

\section{Conclusion}

Accessions 10, 11 and 18 exhibited relatively high DM yield when averaged over the three locations of the study. Accessions 10, 11 and 18 may therefore be considered promising for forage utilization in Benue state. Another regional trial is suggested for the spread of the forage biotypes to other places with similar ecological characteristics.

\section{References}

[1] Adamu. A. M. and M. S. Kallah. 1990. Animal Production on range and Sown Pastures. In: Rangeland/Pasture Development and Management in Nigeria (M. S. Kallah. A. M. Adamu, O. S. Onifade, S. W. Hena and A. A. Abatan (eds.). Training manual Produced by the Livestock Extension Services Unit NAPRI Zaria. pp. 78-93.

[2] Ademosun, A. A. and B. R. Baumgardt. 1967. Studies on the assessment of the nutritive value of some Nigerian forages by analytical methods. Nigerian journal of agricultural science 4(1): 1-7.

[3] Alexander R. H. 1969. The establishment of a laboratory procedure for the 'In-Vitro' Determination of Digestibility. Research bulletin No. 42. The west of Scotland Agricultural College, Scotland, United Kingdom.

[4] AOAC (Association of Official Analytical Chemists) 2000. Official Methods of Analysis (ed. W. Horowitz) $13^{\text {th }}$ Edition Washington D. C. 1,018pp.

[5] Chheda. H. R. and M. E. Aken'Ova. 1982. The improvement elephant grass (Pennisetum purpureum Schum) in Western Nigeria. I. Improvement by selection. Nigerian Agricultural Journal 17/18:209-219.

[6] Crowder. L. V. and H. R. Chheda. (1982) Tropical Grassland Husbandry. Longman Group Limited. 562pp.

[7] Flannery. K. V. 1969. Origin and ecological effects of early domestication in Iran and the Near East. In: P. J. Ucko and G. W. Dimbleby (eds.). The D omestication and Exploitation of Plants and Animals. Gerald Duckworth: London, 110pp.

[8] Koppen W. 1936. Das geographischen system der climate. Hamb. D. Klim., I (C). Boerntraeger, Berlin.

[9] McDonald P. R. A. Edwards J. F. D. Greenhalgh and C. A. Morgan. 1995. Evaluation of foods: In: Animal Nutrition. Fifth Edition, Publ. Longman Scientific Technical, pp.221-473.

[10] Miller. T. B. and A. Blair-Rains 1963. The nutritive value and agronomic aspects of some fodders in Northern Nigeria. I. Fresh herbage. Journal of British Grassland Society 18: 158-167.

[11] MSS (Minitab Statistical Software; Version 16). 2014. Publ. Quickset Inc. Rosemont. PA. Chapter 8: pp. 1-44.

[12] Muhr L., M. Peters, S. A. Tarawali and R. Schultze-Kraft. 1999. Forage legumes for improved fallows in agropastoral systems of subhumid West Africa. III. Nutrient import and export by forage legumes and their rotational effects on subsequent maize. Tropical grasslands 33: 245-256.

[13] Muhr. L., S. A. Tarawali, M. Peters and R. Schultze-Kraft. 2002. Soil mineral $\mathrm{N}$ dynamics and maize grain yields following centrosema macrocarpum and stylosanthes gueanensis: effects of different rotations and varying levels of fertilizer. Field crops research 78: 197-209.

[14] Nyagba. J. L., 1995a. the geography of Benue State. In: Benue, the land of great potentials. A Compendium. D. J. Denga (ed.). First edition. pp. 84-97. 
[15] Remison. S. U. 1978. Evaluation of some pasture species in the Southern Guinea savanna zone of Nigeria. Research Bulletin No. 5. National Cereals Research Institute. Ibadan. 8pp.

[16] Rossiter-Rachor, N. A., S. A. Setterfield, M. M. Douglas, L. B. Hutley, G. D. Cook, S. Schmidt. 2009. Invasive Andropogon gayanus (gamba grass) is an ecosystem transformer of nitrogen relations in Australian savanna. Ecological Applications; Ecological Society of America; Vol: 19, Pp. 1546-1560, 10.1890/08-0265.1.

[17] Tarawali G. and M. A. Mohamed-Saleem. 1995. The role of forage legume fallows in supplying improved feed and recycling nitrogen in sub-humid Nigeria. In: Tarawali G. et $a l \ldots$ eds. Livestock and sustainable nutrient cycling in mixed farming systems of sub-Saharan Africa. 2: technical papers.
Proceedings. Addis-Ababa. Ethiopia. 22-26 November 1993. 263-276.

[18] Tilley T. M. A. and R. A. terry 1963. A two-stage technique of the in-vitro digestion of forage crops. ournal of British Grassland Society 18: 104-111.

[19] Udo. E. E. 1991. Variability in forage characteristics of Andropogon gayanus. Unpublished M. Sc project report. University of Ibadan. 89pp.

[20] Van Soest. P. J. 1967. Development of a comprehensive system of feed analysis and its application to forages. Journal of Animal Science 26: 119-128.

[21] Whiteman. P. C. 1980. Tropical Pasture Science. First Edition Publ. Oxford University press. 392pp. 